\title{
STRUKTUR DAN KONSTRUKSI BANGUNAN STASIUN KA KOTA LAMA (DENGAN PERSANDINGAN STASIUN KA PASARTURI SURABAYA)
}

\author{
Nurachmad Sujudwijono \\ Jurusan Arsitektur, Fakultas Teknik Universitas Brawijaya
}

\begin{abstract}
ABSTRAK
Stasiun Kota Lama dan Stasiun Pasar Turi dibangun pada masa yang hampir sama yaitu pada awal abad ke-20. Kedua stasiun ini dibangun pada masa pemerintahan kolonial Belanda. Keduanya memiliki fungsi yang sama yaitu sebagai peron stasiun, meskipun memiliki bentang yang berbeda. Material kayu dipilih karena kayu adalah sumberdaya yang mudah didapat pada saat itu dan merupakan material yang kuat dan lazim digunakan sebagai struktur bangunan. Pada Stasiun Pasar Turi dan Stasiun Kota Lama menggunakan material kayu yang terbaik, yaitu berupa kayu jati dengan kualitas tinggi, sehingga bangunan tersebut masih bisa bertahan hingga saat ini. Ketersediaan material kayu pada saat itu masih sangat mudah didapatkan dan memiliki kualitas yang baik, berbeda dengan sekarang, dimana kayu merupakan material bangunan yang tegolong mahal karena sumber dayanya yang sudah tidak sebanyak dulu. Dengan pendekatan observasi dan literatur penelitian ini diharapkan mampu menghasilkan gambaran mengenai bagaimana system struktur kayu pada bangunan stasiun Kereta Api Kota Lama dapat bekerja dengan baik dan mampu bertahan hingga saat ini.
\end{abstract}

\section{Kata Kunci: Struktur Kayu, Stasiun, sambungan kayu}

\begin{abstract}
Kota Lama Station and Pasar Turi Station built in almost the same period in the early 20th century. The second station was built in the Dutch colonial administration. Both have the same function, namely as a station platform, although it has a different landscape. Wood materials chosen because the wood is readily available resources at the time and is a strong material and commonly used as a building structure. At Pasar Turi Station and the Kota Lama Station using the best wood material, in the form of teak wood with high quality, so that the building can still survive until today. Wood material availability at the time it was still very easy to obtain and are of good quality, in contrast to today, where the wood is a building material that was expensive because its resources are already not as much as before. With the approach of observation and research literature is expected to produce an overview of how the system structure of wood in buildings of Old Town Railway Station can work well and are able to survive until today.
\end{abstract}

Keywords: wood structure, station, wood connection

\section{Pendahuluan}

Sampai saat ini kayu masih banyak dicari dan dibutuhkan orang. Dari segi manfaatnya bagi kehidupan manusia, kayu dinilai mempunyai sifat-sifat utama yang menyebabkan kayu selalu dibutuhkan manusia. Adapun sifat kayu salah satunya yakni, kayu mempunyai sifat-sifat spesifik yang tidak bisa ditiru oleh bahan lain yang merupakan buatan manusia. Misalnya, kayu mempunyai sifat elastis, ulet, tahan terhadap pembebanan yang tegak lurus dengan seratnya atau sejajar seratnya, dan bebagai sifat lain. Sifat-sifat seperti ini bisa tidak dimiliki baja, beton, atau bahan-bahan 
lainnya yang bisa dibuat oleh manusia.

Kota Malang termasuk kota yang masih mempunyai banyak bangunan yang menggunakan konstruksi kayu. Begitu juga dengan bangunan Stasiun Kota Lama yang berada di kawasan kota lama. Stasiun ini masih mempertahankan konstruksi kayu peninggalan kolonial pada peron kereta yang saat ini masih berdiri kokoh. Jadi kayu ini umurnya sangat panjang, namun peminatnya sangat sedikit. Mereka lebih banyak memilih bahan beton daripada kayu. Karena selain dari segi ekonomi dan perawatannya lebih mahal, kekuatan dan kekokohannya tidak sebaik beton. Namun, di sisi lain dapat kita lihat di stasiun kota lama Malang yang konstruksi peronnya menggunakan kayu, masih dapat berdiri kokoh sampai saat ini.

Seperti halnya di Stasiun Kota Lama Malang, bangunan Stasiun Pasar Turi Surabaya juga masih menggunakan struktur kayu pada bagian peronnya. Penggunaan kayu pada peron Stasiun Pasar Turi Surabaya dikombinasikan dengan kabel baja. Stasiun Pasar Turi juga merupakan salah satu stasiun peninggalan kolonial Belanda yang struktur kayunya masih terawat dan bertahan sampai sekarang. Penggunaan material kayu pada masa itu masih sangat sering digunakan, karena kayu masih banyak tersedia dan mudah didapat.

\section{Tujuan Dan Manfaat Penelitian}

Dengan melakukan penelitian ini, diharapkan penulis dapat mempelajari dan membandingkan ilmu yang telah diperolehnya dengan mengetahui pengetahuan yang didapat langsung di lapangan/pada masa pembuatan konstruksi bangunan kayu jaman penjajahan Balanda abad ke 19 - abad ke 20. Selain itu, berikut adalah beberapa pelajaran penting yang bisa digali, diantaranya:

- Mengetahui struktur dan konstruksi kayu bangunan Stasiun KA Kota Lama Malang dan bangunan Stasiun Pasar Turi Surabaya.

- Mengetahui perbedaan struktur dan konstruksi kayu bangunan Stasiun Kota lama Malang danStasiun Pasar Turi Surabaya.

- Mengetahui perbedaan antara sambungan kayu yang digunakan pada Stasiun Kota Lama dan Stasiun Pasar Turi dengan sambungan Kayu yang sering digunakan saat ini.

\section{Pembahasan}

\subsection{Stasiun Kota Lama Malang}

Bentuk bangunan dari Stasiun Malang Kota Lama sangat sederhana namun memiliki gaya arsitektural menggunakan struktur utama dari material kayu. Struktur utama kayu yang dipadukan dengan dinding bata tebal membuat bangunan ini terlihat cukup kokoh.

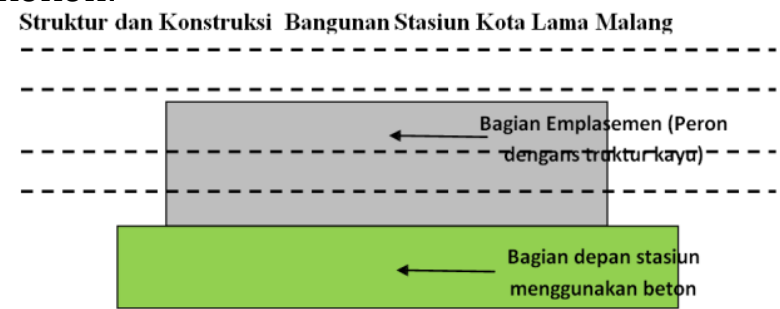

Gambar 1. Bagian Stasiun Kota Lama Malang

Bangunan emplasemen emplasemen tersebut menggunakan struktur kayu dan atap pelana. Pada puncak atap terdapat vestibule yang berfungsi untuk memasukkan 
cahaya matahari.

Detail konstruksi kayu pada pertemuan antara kuda-kuda, kolom dan balok horisontal terlihat sangat kokoh. Banyak bagian yang batangnya terdiri dari batang ganda yang berfungsi sebagai batang tarik.Setiap sambungan diikat dengan pelat baja yang dibaut.
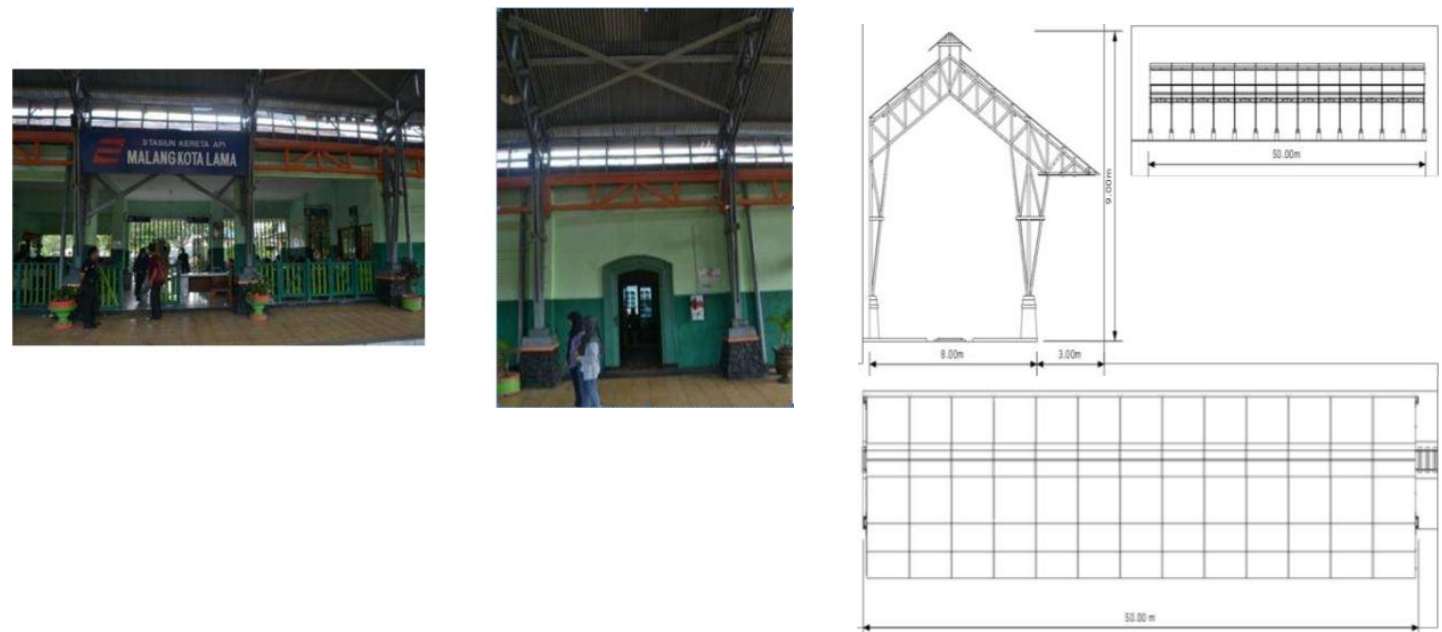

Gambar 2. Tampak depan, tampak samping , tampak atas struktur Stasiun Kota Lama

Dapat terlihat pada gambar di atas bahwa peron ini memiliki panjang sekitar 50 meter. Peron yang sangat terlihat dominasi kayunya ini memiliki jarak antar kolom samping 3,9 meter yang berjumlah 14 buah. Untuk kolom di bagian depan masingmasing berjarak sekitar 8 meter dengan lebar teras rel 3 meter dan lebar rel 2 meter. Tinggi peron ini dari lantai dasar hingga bagian atap yang paling tinggi (terdapat ventilasi) sekitar 9 meter.

\subsubsection{Detail Struktur Bangunan Stasiun Kota Lama Malang}

\section{A. Detail Struktur Nomor 1}
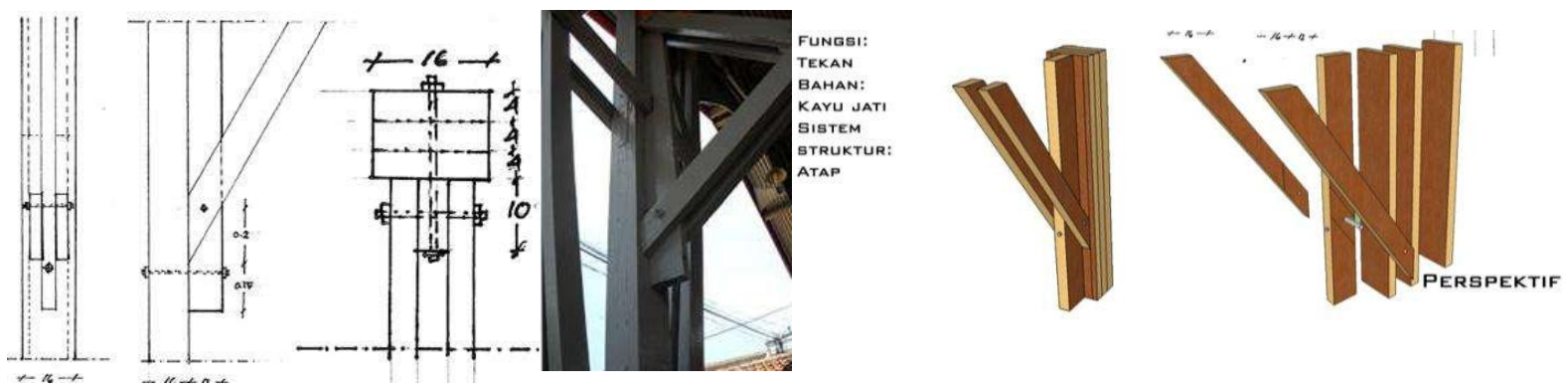

Gambar 3. Detail struktur

Detail sambungan ini terletak pada bagian struktur atap. Terlihat bahwa kayu yang digunakan tidak hanya satu melainkan penggunaan kayu yang berlapis- lapis.

Dapat terlihat bahwa pemasangan kayu yang berlapis-lapis tersebut tidak menggunakan sambungan ikat dengan coakan atau sambungan gapit melainkan didominasi oleh penggunaan sambungan baut. 


\section{B. Detail Struktur Nomor 2}

Seperti detail sambungan yang pertama, detail sambungan ini juga terletak pada bagian struktur atap. Terlihat didominasi oleh penggunaan sambungan baut.
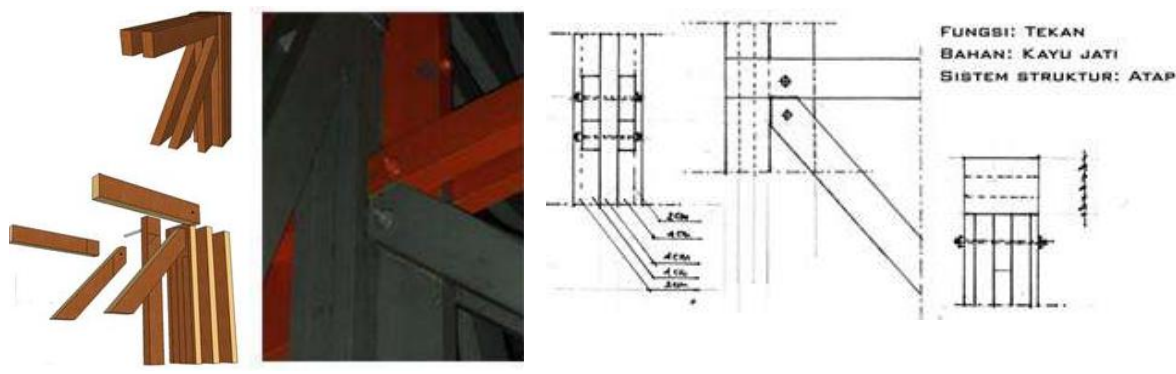

Gambar 4. Detail struktur dan perspektif sambungan kayu no2

C. Detail Struktur Nomor 3
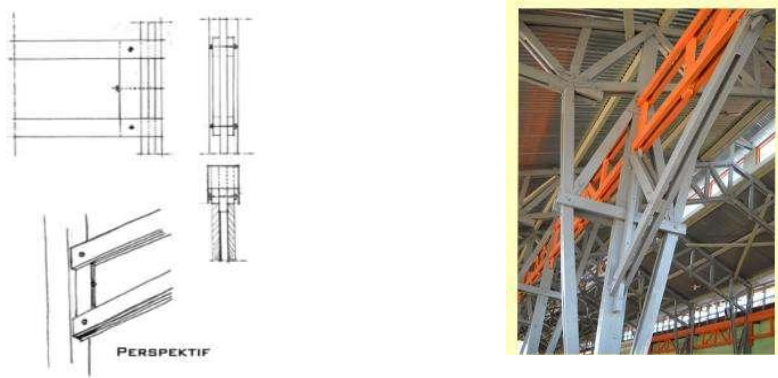

Gambar 5. Detail struktur dan perspektif sambungan kayu no3

D. Detail Struktur Nomor 4
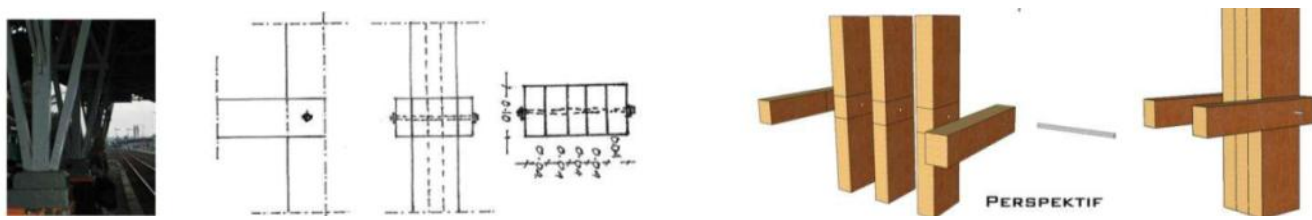

Gambar 6. Detail struktur dan perspektif sambungan kayu no 4

E. Detail Struktur Nomor 5
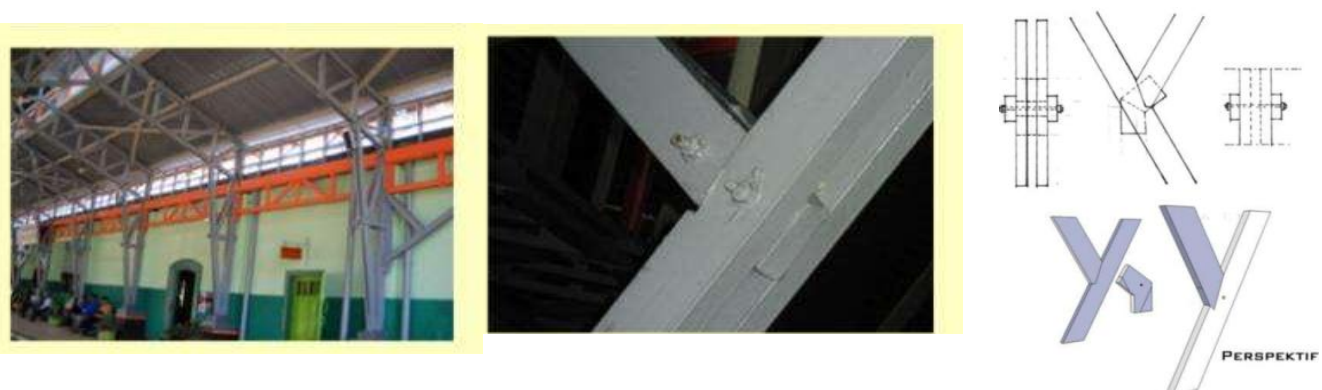

Gambar 7. Detail struktur dan perspektif sambungan kayu no5 
F. Detail Struktur Nomor 6
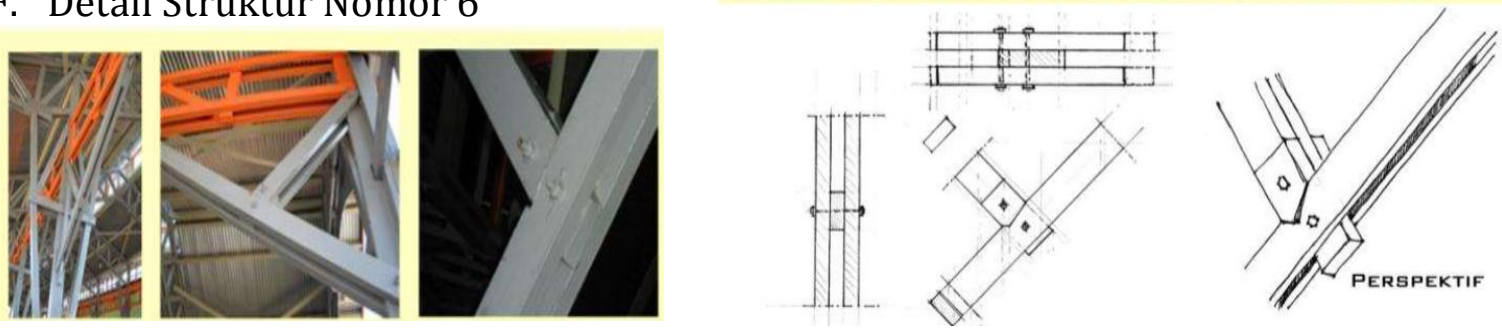

Gambar 8. Detail struktur dan perspektif sambungan kayu no6

G. Detail Struktur Nomor 7
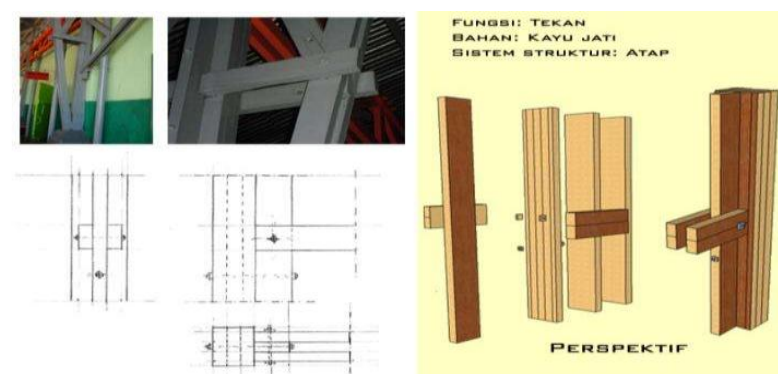

Gambar 9. Detail struktur dan perspektif sambungan kayu no 7

H. Detail Struktur
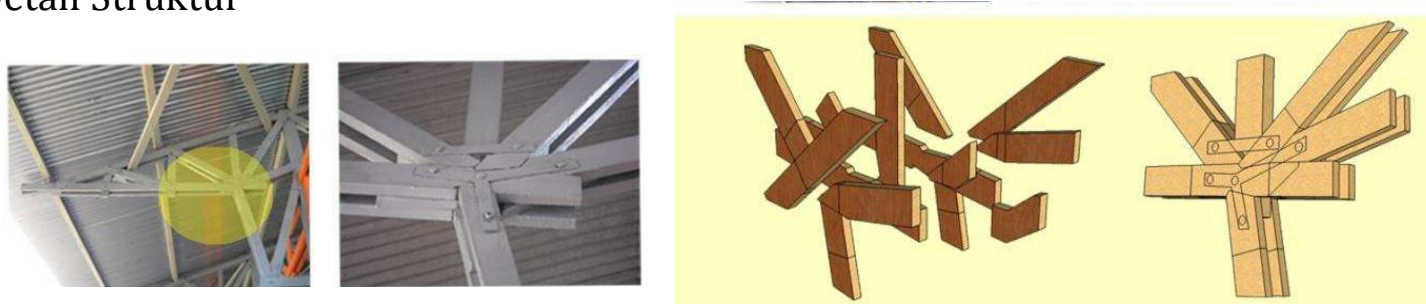

Gambar 10. Detail struktur dan perspektif sambungan kayu no8

\subsubsection{Konstruksi Bangunan Stasiun Kota Lama Malang}

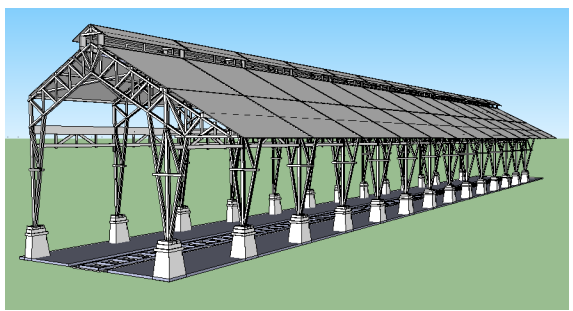

Gambar 11. Perspektif stuktur Stasun Kota Lama Malang Sumber: Hasil penelitian

A. Konstruksi Pondasi, Kaki kolom, dan Kolom

Bangunan kayu umumnya merupakan bangunan relatif ringan dibanding dengan baja maupun beton. 

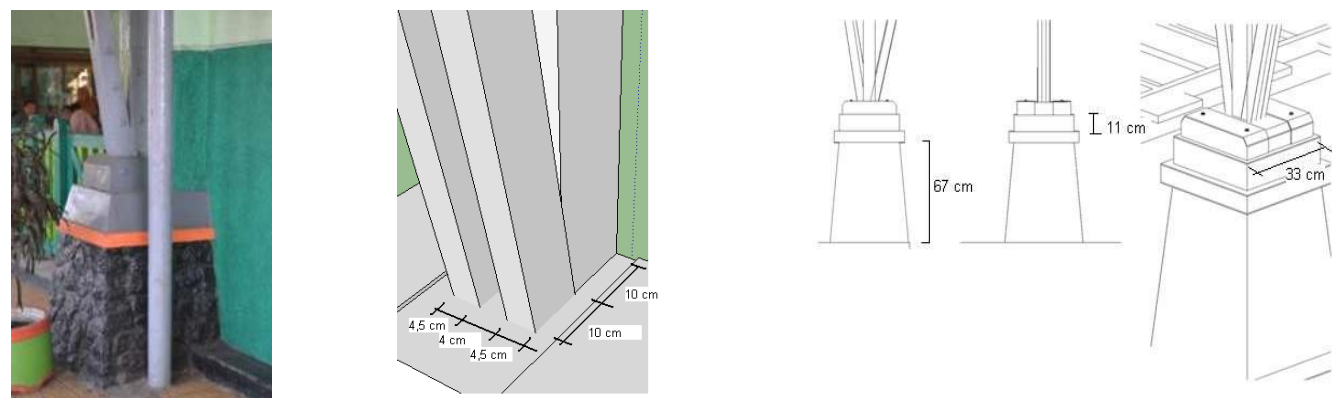

Gambar 12. Kolom kayu dan pondasi umpak pada Stasiun Kota Lama Malang

Kolom kayu dapat berupa kolom tunggal, kolom gabungan dan kolom dari produk kayu laminasi. Kolom gabungan dapat disusun dari dua batang kayu atau berupa papan yang membentuk bangun persegi.
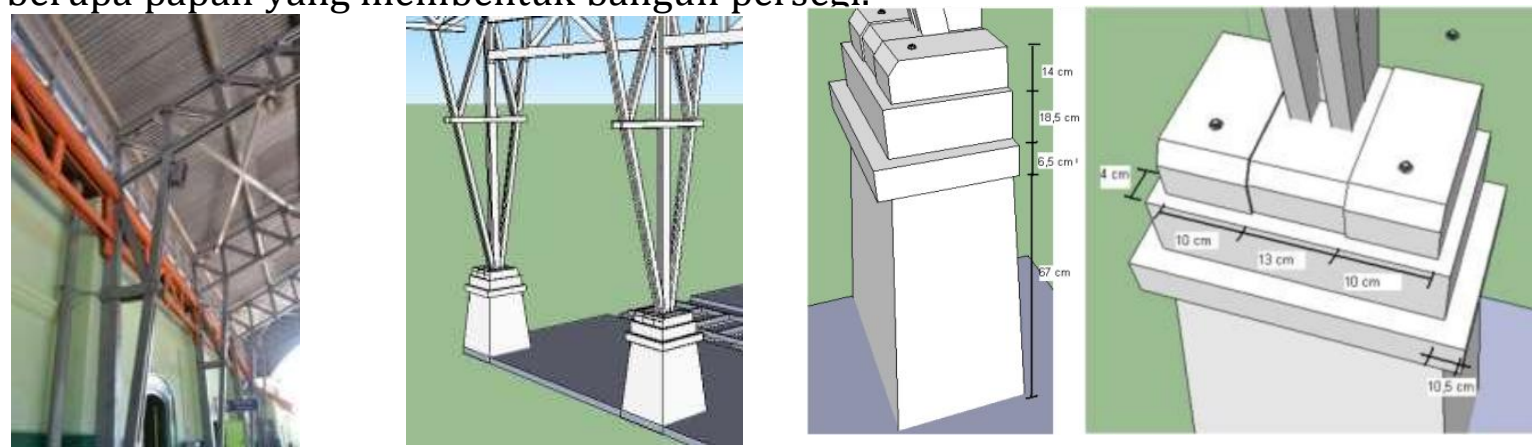

Gambar 13. Batang kolom kayu dan detail pondasi umpak Stasiun Kota Lama Malang

Penggunaan klos sambung mungkin akan cukup baik, namun akan menjadi mahal karena menambah volume kayu yang tidak sedikit. Penyelenggaraan sambungan yang mendekati ideal dapat menggunakan pelat sambung seperti yang ditunjukkan pada gambar. Dengan penggunaaan alat sambung kolom dengan balok tersebut, pengurangan tampang kolom yang terjadi hanya akibat lubang baut.

\section{B. Konstruksi Balok}

Pada bangunan gedung, struktur balok dapat berupa balok loteng, balok atap, maupun gording.. Untuk penyambungan, batang balok dengan balok perlu menghindari sambungan yang menerima momen yang relatif besar. Karenanya sambungan balok umumnya dilakukan tepat di atas struktur dudukan atau mendekati titik dudukan. Dengan begitu momen yang terjadi pada sambungan relatif kecil.

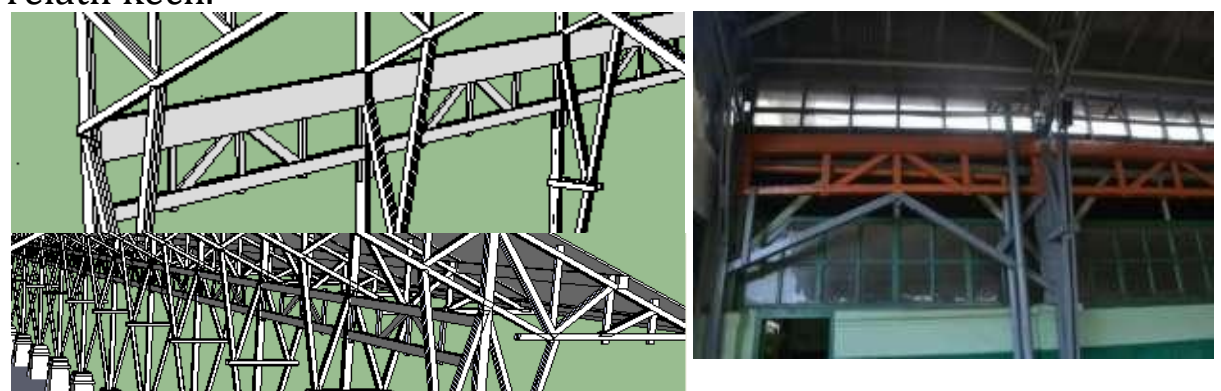

Gambar 14. Model balok kayu Stasiun Kota Lama Malang 
Kayu merupakan bahan yang higroskopis, mudah mengembang atau menyusut oleh kadar air. Pada pembuatan sambungan dengan bahan lain, misal plat baja, hindarkan sobek batang struktur akibat sifat kembang dan susut kayu. Hal ini karena angka muai baja dan kayu saling berkebalikan. Salah satu cara menghindari sobek akibat kembang dan susut kayu adalah dengan cara memisah/memecah plat baja.

\section{Konstruksi rangka batang kayu}

Rangka batang merupakan struktur rangka yang disusun batang membentuk bangun segitiga dengan simpul/titik sambung, dapat menerima beban struktur. Fungsi lain pada bagian atas terdapat struktur atap ganda yaitu atap utama dan atap ventilasi.

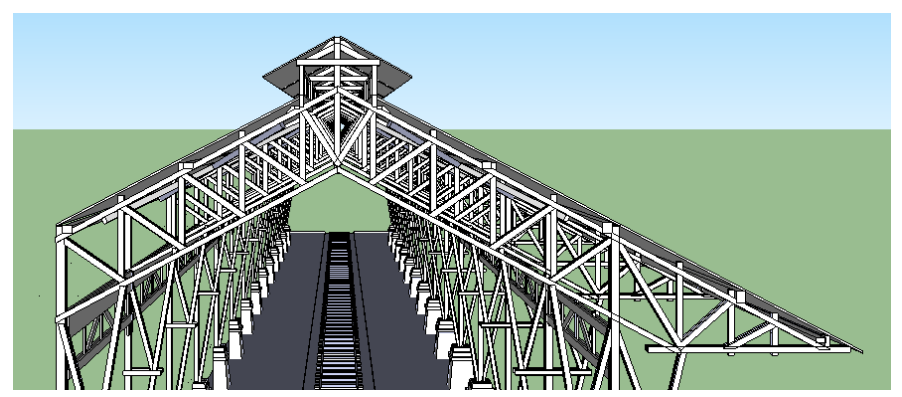

Gambar 15. Rangka batang kayu Stasiun Kota Lama Malang

\subsection{Stasiun KA Pasar Turi Surabaya}

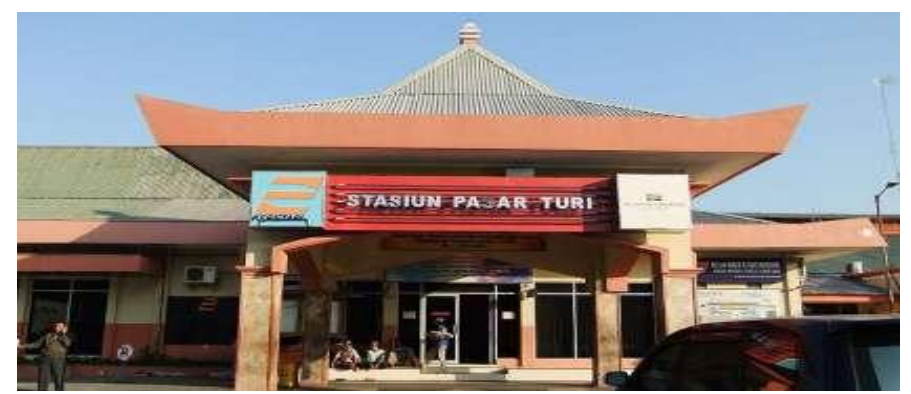

Gambar 16. Stasiun Pasar Turi Surabaya

Stasiun Pasar Turi adalah salah satu stasiun besar yang terletak di Surabaya Jawa Timur. Stasiun ini dibangun sekitar pada tahun 1920. Bagian yang akan kami amati pada Stasiun Pasar Turi adalah peron stasiunnya. Atap peron stasiun pasar turi terbuat dari kayu, dengan sambungan kuda-kuda unik yang menggabungkan antara kekuatan kayu dan kabel baja. Dibandingkan dengan peron Stasiun Maang Kota lama, peron Stasiun Pasar Turi memiliki bentang yang lebih lebar dan dibangun pada masa yang berbeda, sehingga memiliki teknologi pembangunan yang berbeda karena menggabungkan teknologi kayu dan kabel baja. 


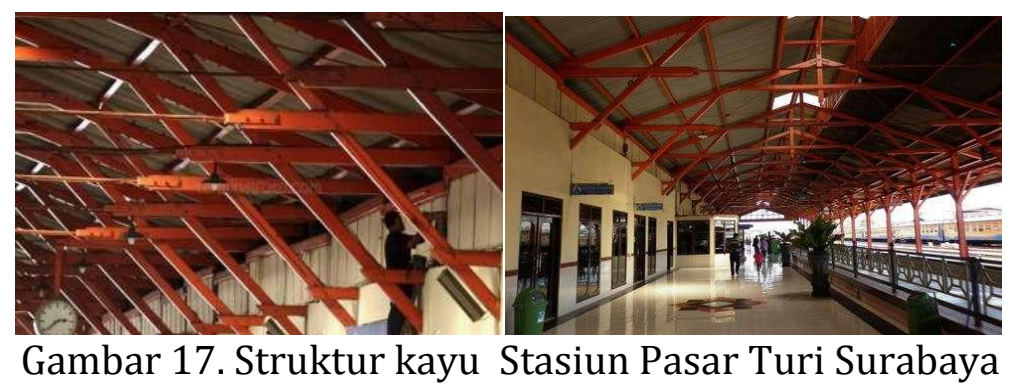

Struktur kayu yang digunakan pada stasiun pasar turi adalah struktur kuda- kuda kayu biasa yang sering digunakan untuk struktur atap. Bangunan peron stasiun pasar turi memiliki bentang yang cukup besar yaitu 14 meter, karena bentangnya yang sangat lebar, digunakan kabel untuk menggantikan balok kuda- kuda, dengan pertimbangan bahwa kabel memiliki daya tarik yang kuat.

Struktur sambungan yang banyak digunakan pada kuda-kuda peron Stasiun Pasar Turi adalah sambungan jepit dengan aplikasi pelat dan baut. Kayu yang digunakan juga merupakan kayu terbaik, yang dapat bertahan sejak pertama dibangun pada tahun 1920 hingga saat ini.
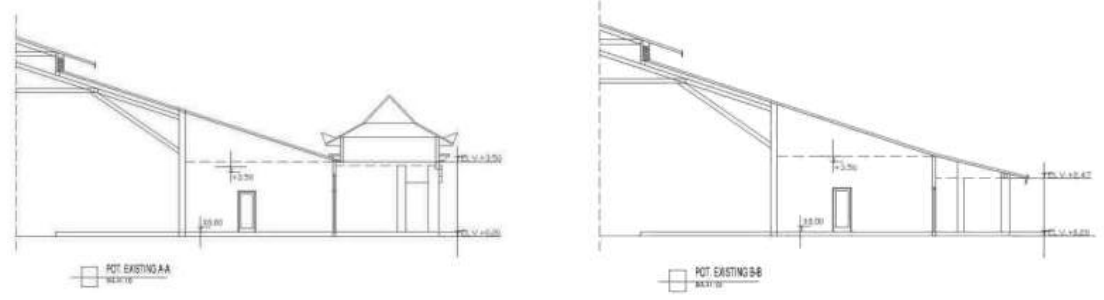

Gambar 18. Potongan Stasiun Pasar Turi Surabaya

\subsubsection{Detail Sambungan pada Kuda-kuda Kayu Stasiun Pasar Turi Surabaya}
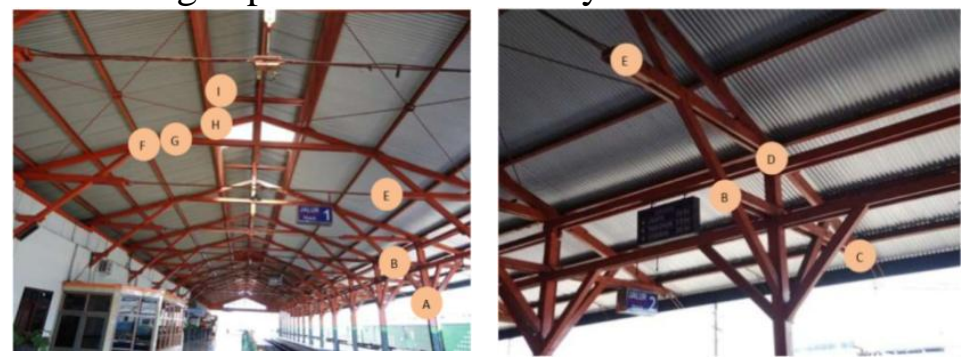

Gambar 19. Struktur kayu Stasiun Pasar Turi Surabaya

Berikut adalah beberapa detail sambungan kayu yang ada pada peron Stasiun Pasar Turi Surabaya:

A. Detail Sambungan A
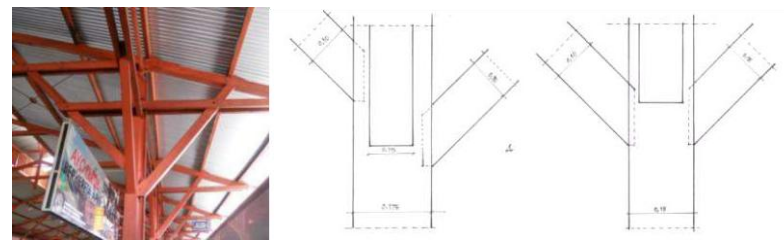

Gambar 20. Detail sambungan A

Jenis sambungan ini adalah sambungan yang memiliki gaya tekan (sambungan tekan). 
B. Detail sambungan B

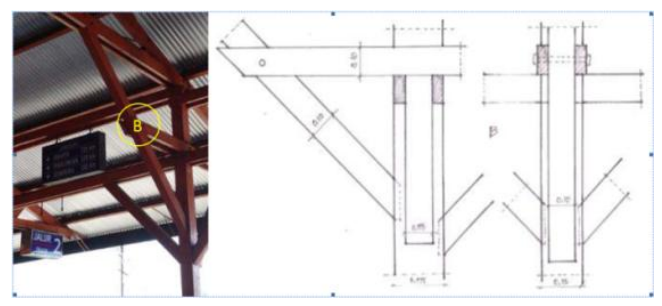

Gambar 21. Detail sambungan B

Sambungan jepit biasanya digunakan sebagai pengaku atau penguat. Pada sambungan jepit B untuk hubungan antar kayu diperkuat dengan penggunaan baut.

C. Detail sambungan C
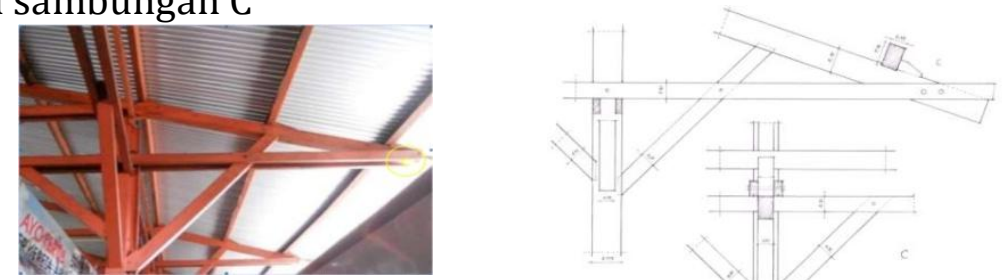

Gambar 22. Detail sambungan C

Pada sambungan jepit digunakan system coakan dan takikan serta baut untuk memperkuat sambungan. Pada peletakan balok gording digunakan klos untuk menahan balok gording tetap pada tempatnya, peletakan balok gording dan klos diperkuat dengan menggunakan paku.

D. Detail sambungan D
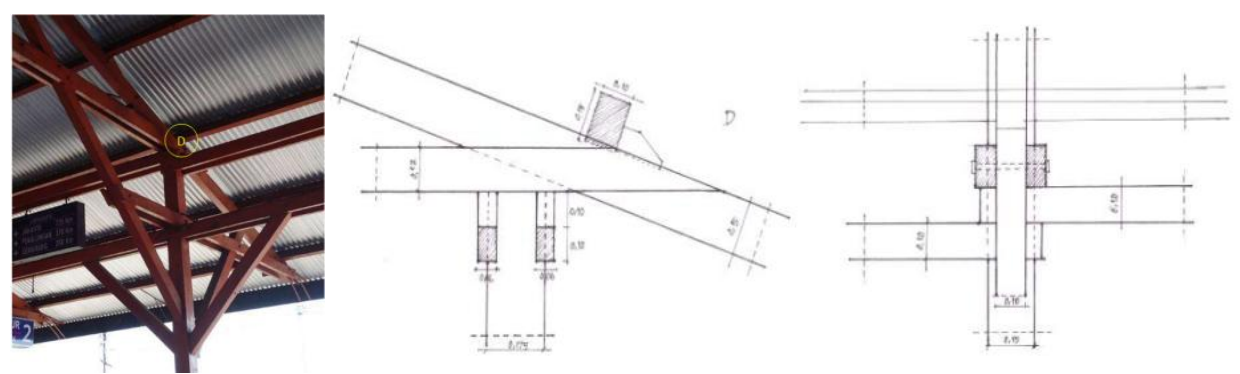

Gambar 23. Detail sambungan D

Pada sambungan jepit digunakan system coakan dan takikan serta baut dan pelat untuk memperkuat sambungan. Pada peletakan balok gording digunakan klos untuk menahan balok gording tetap pada tempatnya, peletakan balok gording dan klos diperkuat dengan menggunakan paku. 
E. Detail sambungan E
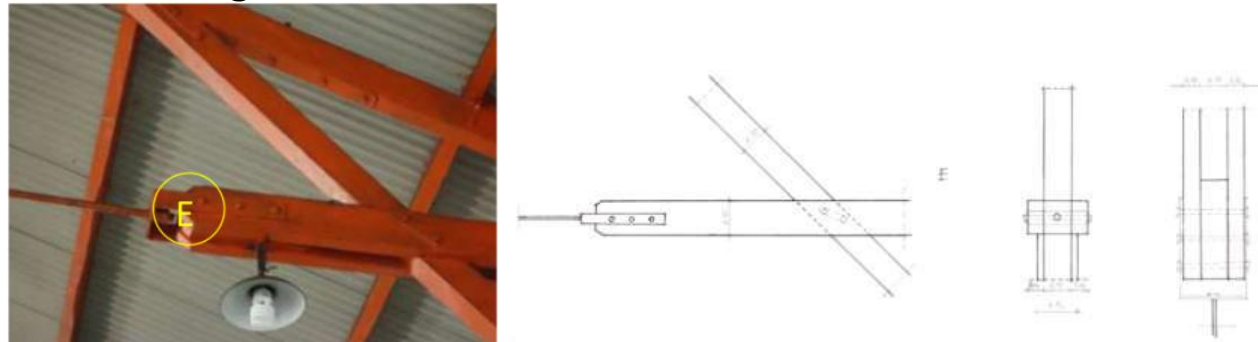

Gambar 24. Detail sambungan E

Kabel baja digunakan untuk mengganti balok kuda-kuda. Pada sambungan ini terdapat gaya tarik yang disebabkan oleh kabel baja, maka sambungan ini adalah sambungan tarik.

F. Detail sambungan F
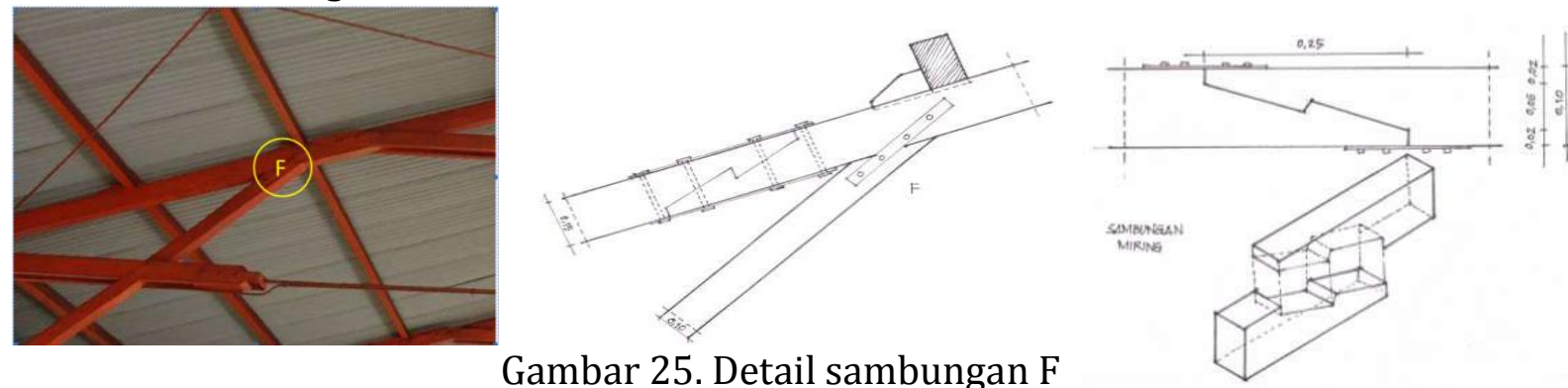

Gambar 25. Detail sambungan F

Sambungan yang terdapat pada bagian ini adalah sambungan tekan. Sambungan bibir miring ini adalah jenis sambungan yang memiliki gaya tarik (sambungan tarik). Baut dam plat digunakan untuk memperkuat sambungan kayu.

G. Detail sambungan G
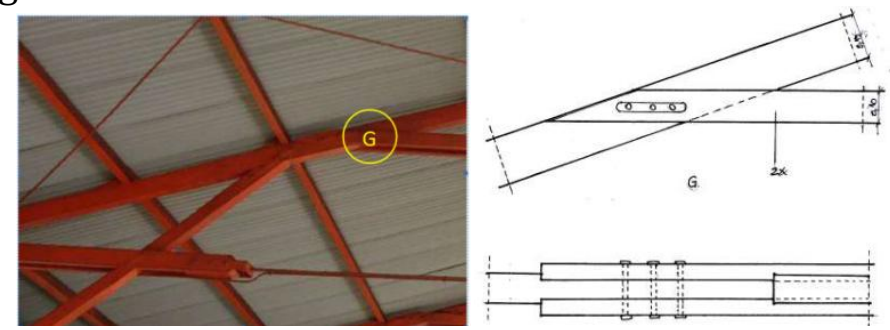

Gambar 26. Detail sambungan G

Sisi miring kuda-kuda dijepit dengan 2 batang kayu yang melintang. Sambungan jepit diperkuat dengan menggunakan plat dan baut dan merupakan sambungan tekan.

H. Detail Sambungan H
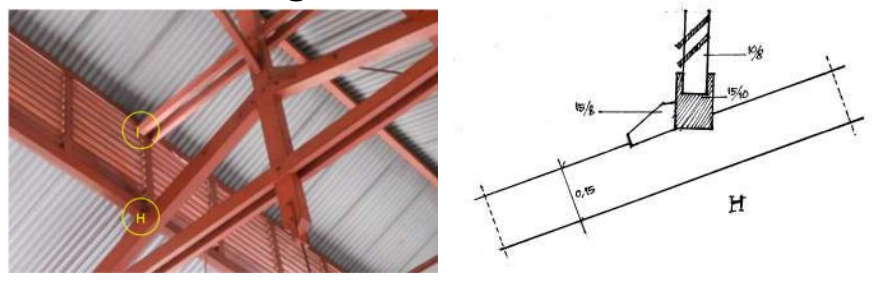

Gambar 27. Detail sambungan H 
Pada bagian atas kuda-kuda terdapat ventilasi atap. Gording diletakkan di atas sisi miring kuda-kuda dengan sedikit coakan dan ditahan dengan menggunakan klos. Bagian tersebut adalah sambungan tekan.

I. Detail sambungan I
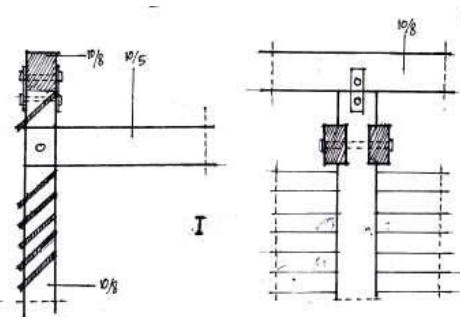

Gambar 28. Detail sambungan I

Pada bagian ini, untuk menyambung kayu satu dengan kayu yang lain adalah dengan menggunakan plat dan baut.

\subsection{Perbandingan Struktur Stasiun KA Kota Lama dan Stasiun KA Pasar Turi}

Setelah dianalisis mengenai struktur dan konstruksi bangunan kayu dari Stasiun Kota Lama Malang dan Stasiun Pasar Turi Surabaya, berikut adalah perbandingan mengenai struktur dan konstruksi kayu dari bangunan peron kedua stasiun.

\subsubsection{Material yang Digunakan}

Material yang digunakan pada bangunan stasiun kota lama Malang ini adalah kayu. Kayu yang digunakan adalah kayu jati yang berusia cukup tua, sehingga kuat dan kokoh. Pada Stasiun Pasar Turi, kayu yang digunakan juga adalah kayu jadi, namun dipadukan dengan penggunaan kabel baja dan baja. Karena bentangnya yang lebih besar, maka Stasiun Pasar Turi menggunakan kabel baja untuk mengganti balok kuda-kuda, dan memperkuat kolom kayu.

Material penutup atap yang digunakan pada kedua stasiun ini adalah asbes. Asbes yang relative ringan menyebabkan beban yang akan diterima kuda-kuda dan kolom menjadi tidak terlalu besar, selain itu asbes juga tergolong penutup atap yang cukup awet dan kuat, tidak mudah rusak, asbes memiliki sifat yang tidak menyerap panas, dan harganya tergolong cukup terjangkau. Penggunaan atap asbes juga memiliki efek samping yang berbahaya, asbes dapat menimbulkan asbestosis. Asbestosis adalah suatu penyakit yang menyerang organ pernafasan, yaitu paru-paru, penyakit ini timbul karena manusia menghirup partikel-partikel kecil yang berasal dari bahan asbes.

\subsubsection{Struktur Bangunan}

\section{A. Stasiun Kota Lama Malang}

Selain karena kualitas bahan yang digunakan, teknik yang digunakan untuk membuat konstruksi kayu ini juga mempengaruhi keawetannya hingga sekarang. Stasiun Kota Lama Malang menggunakan kolom kayu dengan konstruksi ganda yang terdiri dari batang tegak dan batang miring membuat struktur ini lebih kuat. Rangka atap di Stasiun Kota Lama Malang menggunakan konstruksi dengan sistem truss dan tetap menggunakan konstruksi ganda dengan sistem jepit.

Pada bagian balok, juga menggunakan sistem truss sehingga dapat menyalurkan beban horizontal menuju kolom dan konstruksi menjadi lebih kokoh. 
Hampir semua bagian pada bangunan Stasiun Kota Lama ini menggunakan sistem sambungan jepit.

Setiap sambungan diikat dengan pelat baja yang dibaut. Ukuran baut yang digunakan relatif besar.

\section{B. Stasiun Pasar Turi}

Pada Stasiun Pasar Turi, rangka atap yang digunakan adalah rangka atap konvensional. Teknik yang digunakan juga sama, yaitu saling menyambung kayu dengan baut, namun perbedaannya terdapat pada ukuran baut yang lebih kecil.

Beberapa bagian menggunakan konstruksi ganda dengan sistem jepit. Hal tersebut dapat dilihat pada bagian kuda-kuda dan pada balok. Pada Stasiun pasar Turi, juga digunakan material berupa kabel baja untuk mengganti balok kuda- kuda. Kabel baja digunkan karena peron stasiun ini memiliki bentng yang cukup besar yaitu 14 meter, jika digunakan kayu, maka akan terdapat beberapa sambungan pada kayu yang dapat mengurangi kekuatan kayu. Kabel baja sendiri dikenal memiliki daya tarik yang kuat, sehingga diharapkan dapat menahan beban yang besar.

\subsubsection{Bentang}

Kedua stasiun ini memilki bentang yang berbeda. Stasiun Kota Lama Malang memiliki bentang yang lebih kecil yaitu $8 \mathrm{~m}$. Sedangkan Stasiun Pasar Turi memiliki bentang $14 \mathrm{~m}$. Karena memiliki bentang yang berbeda, kedua stasiun ini menggunakan struktur dan dimensi kayu yang berbeda.

\subsubsection{Dimensi kayu}

Dimensi kayu yang digunakan pada kedua stasiun berbeda. Stasiun Pasar Turi menggunakan dimensi kayu 6/12, 8/12 dan 8/15 dan 15/19 pada bagian kolom. Stasiun Kota Lama Malang menggunakan kayu dengan dimensi 10/14, 13/14, 4/10, $4,5 / 10$, dan yang terbesar adalah 10,5/18,5. Penggunaan dimensi kayu ini dalam sejarahnya mengakibatkan kerugian dan keborosan yang cukup tinggi.

Pada stasiun Kota Lama Malang, kayu yang digunakan memiliki ukuran yang relative lebih kecil dan pendek, hal ini disebabkan karena bentangnya yang tidak terlalu besar. Penggunaan struktur truss juga mempengaruhi ukuran kayu, karena penggunaan struktur truss, maka kayu yang dibutuhkan berukuran kecil dan pendek.

\subsubsection{Pondasi}

Pada bagian pondasi, bila stasiun pasar Turi menggunakan pondasi umpak dengan campuran semen, pada pondasi umpak stasiun kota lama Malang tidak menggunakan semen. Menurut sumber yang penulis dapat, alat perekat untuk pembuatan pondasi pada jaman Belanda menggunakan campuran batu gamping, pasir, dan gula tetes, yang masih kuat hingga sekarang walau tanpa semen.

Kedua bangunan menggunakan pondasi umpak, karena kolomnya yang terbuat dari kayu, maka digunakan pondasi umpak untuk mencegah kolom kayu terkena air tanah dan menjadi rusak dan rapuh. Karena kedua fungsi bangunan adalah sebagai peron stasiun, maka penggunaan pondasi umpak juga diharapkan dapat mereduksi dampak getaran yang disebabkan oleh kereta api yang lewat. 


\subsubsection{Teknik Sambungan Kayu}

Pada Stasiun Pasar Turi banyak digunakan sambungan-sambungan jepit yang diperkuat dengan baut dan pelat, ditemukan juga teknik sambungan kayu secara memanjang dengan menggunakan sambungan bibir miring berkait. Pada Stasiun Malang Kota Lama teknik sambungan yang digunakan juga memakai pelat dan baut untuk memperkuat sambungan kayu. Terdapat juga sambungan jepit pada beberapa bagian yang berfungsi sebagai penguat dan pengaku struktur kayu.

Sistem struktur kayu dan sambungan yang digunakan pada Stasiun Pasar Turi relatif lebih sederhana bila dibandingkan dengan yang digunakan pada Stasiun Kota Lama. Hal ini dipengaruhi oleh struktur kuda-kuda yang digunakan. Pada Stasiun Pasar Turi menggunakan rangka kuda-kuda biasa, sedangkan pada Stasiun Kota Lama menggunakan sistem truss.

\section{Kesimpulan}

Stasiun Kota Lama Malang yang dibangun pada tahun 1879 menggunakan konstruksi kayu pada bagian emplasemennya dengan bentang 8 meter dan didominasi oleh sistem truss. Stasiun Pasar Turi Surabaya yang dibangun pada tahun 1920an juga menggunakan struktur kayu pada emplasemennya. Terdapat perbedaan pada sistem struktur dan detil-detil konstruksi antara keduanya.

\section{DAFTAR PUSTAKA}

Anonim. 2008. Semua Tentang Kayu: Pengawetan Kayu. Entry from: http://www.tentangkayu.com/2008/07/pengawetan-kayu.html (12 Juli 2012) . 2009. Teknik Struktur Bangunan dengan Konstruksi Kayu. Entry from: http://www.crayonpedia.org/mw (10 Agustus 2012)

2011. Cara Pengawetan Kayu Bahan Bangunan. Entry from: http://www.ilmusipil.com/cara-pengawetan-kayu-bahan-bangunan $\quad(12$ Juli 2012)

2010. Arsip untuk Konstruksi Kayu. Entry from: http://xdesignmw.wordpress.com/category/konstruksi-kayu/ (30 Agustus 2012)

Antok. 2009. Cara Pengawetan Kayu. Entry from: http://noviantoblog.blogspot.com/2009/10/cara-pengawetan-kayu.html (12 Juli 2012)

Felix, KH. 1984. Konstruksi Kayu. Bandung: Binacipta

Kementrian Kehutanan RI. Pengenalan Jenis Kayu: Manfaat Pengenalan Jenis Kayu. Entry from: http://www.dephut.go.id/Halaman/STANDARDISASI \& LINGKUNGAN KEHUT ANAN/INFO III01/III III01.html (12 Juli 2012)

PT. KAI Kota Malang. 2010. Stasiun Kota Lama Malang. Entry from: http://indonesianheritagerailway.com/ (14 November 2011)

Sakaruhun, Akas. 2011. Jenis dan Ukuran Kayu. Entry from: http://putrasakaruhun.blogspot.com/p/jenis-ukuran-kayu 04.html (12 Juli 2012)

Sarastiana. 2011. Struktur Atap. Entry from: http://sarastiana.com/2011/06/02/struktur-atap-2/ (2 September 2012)

Stefford, John. 1986. Teknologi Kerja Kayu. Jakarta: Erlangga

Sugihardjo, R. 1963. Gambar-gambar Dasar Ilmu Bangunan. Yogyakarta: Mataram 